\title{
Effects of ferulic acid esterase-producing Lactobacillus fermentum and cellulase additives on the fermentation quality and microbial community of alfalfa silage
}

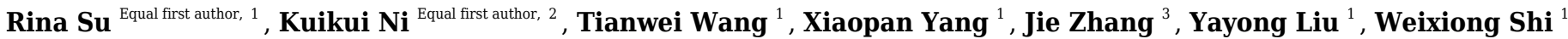 \\ , Liu Yan ${ }^{4}$, Chen Jie ${ }^{4}$, Jin Zhong ${ }^{\text {Corresp. } 3}$ \\ ${ }^{1}$ School of Life Science, University of Chinese Academy of Sciences, Beijing, China \\ 2 College of Grassland Science and Technology, China Agricultural University, Beijing, China \\ 3 State Key Laboratory of Microbial Resources, Institute of Microbiology, Chinese Academy of Sciences, Beijing, China \\ 4 Hebei Zhongyuzhongke biotechnology development company, Hebei, China \\ Corresponding Author: Jin Zhong \\ Email address: zhongj@im.ac.cn
}

Background. Alfalfa (Medicago sativa) is an important forage material widely used for animal feed production. Ensiling is an effective method for preserving alfalfa, but it has shown some limitations in the production of high-quality alfalfa silage due to its low water soluble carbohydrates (WSC) content and high buffering capacity. Lactic acid bacteria (LAB) and cellulase are often used as silage additives to promote the ensiling process and enhance fermentation quality.

Methods. Experiments were conducted to investigate the effects of ferulic acid esterase (FAE)-producing Lactobacillus fermentum 17SD-2 (LF) and cellulase (CE) on the fermentation quality and microbial community of alfalfa silage. After 60 days of ensiling, analysis of fermentation quality and bacterial diversity in alfalfa silages were conducted using high-performance liquid chromatography and highthroughput sequencing methods.

Results. Alfalfa was ensiled with additives (LF, CE, and LF+CE) or without additives for 60 days. All additives increased lactic acid and decreased $\mathrm{pH}$ values and ammonia-N contents compared to control. Among all treatments, the combined addition of LF and CE showed lowest $\mathrm{pH}(4.66)$ and ammonia-N $\left(\mathrm{NH}_{3}-\mathrm{N}, 0.57 \% \mathrm{DM}\right)$ content, highest contents of lactic acid (LA, 10.51\% DM), dry matter (DM, 22.54\%) and crude protein (CP, 24.60\% DM). Combined addition of LF and CE performed better in reducing neutral detergent fiber (NDF, 29.76\% DM) and acid detergent fiber (ADF, 22.86\% DM) contents than the addition of LF $(33.71,27.39 \%$ DM) or CE $(32.07,25.45 \%$ DM) alone. Moreover, the microbial analysis indicated that LF+CE treatments increased the abundance of desirable Lactobacillus and inhibited the growth of detrimental Enterobacter and Clostridia in alfalfa silage.

Discussion. Combined addition of FAE-producing LF and CE is more effective than treatments of LF or $C E$ alone in improving fermentation quality and nutrition values of alfalfa silage. This is likely due to a synergistic effect of CE and FAE produced by LF on plant cell wall degradation, indicating that these additives promote each other to improve fiber degradation and silage fermentation. In conclusion, combined addition of FAE-producing LF and CE could be a feasible way to improve alfalfa silage quality. 


\section{Effects of ferulic acid esterase-producing Lactobacillus fermentum}

\section{2 and cellulase additives on the fermentation quality and microbial}

3 community of alfalfa silage

4 Rina $\mathrm{Su}^{1,2} \uparrow$, Kuikui $\mathrm{Ni}^{3 \dagger}$, Tianwei Wang ${ }^{1,2}$, Xiaopan Yang ${ }^{1,2}$, Jie Zhang ${ }^{1,2}$, Yayong Liu ${ }^{1,2}$,

5 Weixiong Shi ${ }^{1,2}$, Yan Liu ${ }^{4}$, Jie Chen ${ }^{4}$, Jin Zhong ${ }^{1,2 *}$

${ }^{1}$ State Key Laboratory of Microbial Resources, Institute of Microbiology, Chinese Academy of

8 Sciences, Beijing 100101, China

$9{ }^{2}$ School of Life Science, University of Chinese Academy of Sciences, Beijing 100039, China

${ }^{3}$ College of Grassland Science and Technology, China Agricultural University, Beijing, China

${ }^{4}$ Hebei Zhongyuzhongke biotechnology development company, Hebei 065000, China

*Corresponding Author:

Jin. Zhong

NO. 1 Beichen West Road, Chaoyang District, Beijing 100101, China

Email address: zhongj@im.ac.cn

$\dagger$ These authors have contributed equally to this work and should be considered co-first authors.

\section{ABSTRACT}

Background. Alfalfa (Medicago sativa) is an important forage material widely used for animal feed production. Ensiling is an effective method for preserving alfalfa, but it has shown some limitations in the production of high-quality alfalfa silage due to its low water soluble carbohydrates (WSC) content and high buffering capacity. Lactic acid bacteria (LAB) and cellulase are often used as silage additives to promote the ensiling process and enhance fermentation quality.

Methods. Experiments were conducted to investigate the effects of ferulic acid esterase (FAE)producing Lactobacillus fermentum 17SD-2 (LF) and cellulase (CE) on the fermentation quality and microbial community of alfalfa silage. After 60 days of ensiling, analysis of fermentation quality and bacterial diversity in alfalfa silages were conducted using high-performance liquid chromatography and high-throughput sequencing methods.

Results. Alfalfa was ensiled with additives (LF, CE, and LF+CE) or without additives for 60 days. All additives increased lactic acid and decreased $\mathrm{pH}$ values and ammonia- $\mathrm{N}$ contents compared to 
control. Among all treatments, the combined addition of LF and CE showed lowest $\mathrm{pH}$ (4.66) and ammonia- $\mathrm{N}\left(\mathrm{NH}_{3}-\mathrm{N}, 0.57 \% \mathrm{DM}\right)$ content, highest contents of lactic acid (LA, 10.51\% DM), dry matter (DM, 22.54\%) and crude protein (CP, 24.60\% DM). Combined addition of LF and CE performed better in reducing neutral detergent fiber (NDF, 29.76\% DM) and acid detergent fiber (ADF, 22.86\% DM) contents than the addition of LF $(33.71,27.39 \% \mathrm{DM})$ or CE $(32.07,25.45 \%$ $\mathrm{DM})$ alone. Moreover, the microbial analysis indicated that LF+CE treatments increased the abundance of desirable Lactobacillus and inhibited the growth of detrimental Enterobacter and Clostridia in alfalfa silage.

Discussion. Combined addition of FAE-producing LF and CE is more effective than treatments of $\mathrm{LF}$ or $\mathrm{CE}$ alone in improving fermentation quality and nutrition values of alfalfa silage. This is likely due to a synergistic effect of CE and FAE produced by LF on plant cell wall degradation, indicating that these additives promote each other to improve fiber degradation and silage fermentation. In conclusion, combined addition of FAE-producing LF and CE could be a feasible way to improve alfalfa silage quality.

\section{Keywords: Ferulic acid esterase, Lactobacillus fermentum, Cellulase, Alfalfa, Silage}

\section{INTRODUCTION}

Alfalfa is widely used for animal feed in the world due to its high protein content. However, the low concentration of WSC and high buffering capacity in alfalfa makes it difficult to ensile for high silage quality (Silva et al., 2016). In order to enhance fermentation quality, lactic acid bacteria (LAB) and cellulase are often used as silage additives. LAB can accelerate lactic acid fermentation and reduce nutrition loss during the ensiling process (Gulfam et al., 2017). Cellulase can degrade the plant cell wall and improve the ruminal digestibility of silage (Khota et al., 2016).

Ferulic acid ester usually links ferulic acid with polysaccharides in plant cell walls, which results in extended networks and forms a protective layer. Ferulic acid esterase (FAE) can break the ester linkage between the ferulate and polysaccharide chain, and then enhance the accessibility of cellulase and hydrolyze the cell wall (Koseki, et al., 2009). Well-characterized FAEs are mainly from fungi (Faulds et al., 2005), but now some researchers are increasingly studying FAEproducing bacteria due to their practical application value (Fritsch et al., 2017).

For silage fermentation, Jin et al reported that mixed small-grain silage treated with FAEproducing Lactobacillus buchneri had higher in situ NDF digestibility than control. Furthermore, pretreatment with $L$. plantarum A1 (FAE activity) alone or in combination with exogenous cellulase had a synergistic effect on corn stalk silage fermentation and degradation of lignocellulase (Li et al., 2019), such as producing more available substrates for LAB fermentation. However, the effects of FAE-producing LAB inoculant on silage quality can be highly variable, 
possibly due to the different forage varieties and performance differences in LAB strains (Lynch et al., 2015; Jin et al. 2017; Li et al., 2019).

The potential of FAE activity LAB to improve silage quality or fiber digestibility of various silages includes barley, ryegrass and corn have been reported (Addah et al., 2012; Nsereko et al., 2007; Kang et al., 2009). But there is little information about the application of FAE activity LAB or its combination with exogenous cellulase on alfalfa silage. We hypothesized that the combination of FAE-producing LF and CE will improve the fermentation quality and nutrition values more effectively in alfalfa silage. In order to verify the hypothesis, experiments were carried out as follows: characterize FAE activity $L$. fermentum 17SD-2; investigate the effects of $L$. fermentum 17SD-2 (LF), cellulase (CE), or their combination on the fermentation quality and bacterial community of alfalfa silage.

\section{MATERIALS AND METHODS}

\section{Identification of FAE activity in Lactobacillus fermentum 17SD-2}

Lactobacillus fermentum 17SD-2 used in this study was isolated from maize silage without any additives, then maintained in De Man, Rogosa, and Sharpe (MRS) broth containing 20\% (v/v) glycerol at $-80^{\circ} \mathrm{C}$. Before any experiments, the strain was propagated twice and cultured in MRS broth for $24 \mathrm{~h}$ at $37^{\circ} \mathrm{C}$, harvested by centrifugation $(10,000 \mathrm{rpm}, 2 \mathrm{~min})$, and washed twice with phosphate buffered saline (PBS, pH 7.0). The sediment was resuspended in sterile water and 10 $\mu \mathrm{L}$ of the suspension was transformed to MRS plates with glucose omitted but containing $1 \mathrm{~g} / \mathrm{L}$ ethyl ferulate and incubated for $72 \mathrm{~h}$ at $37^{\circ} \mathrm{C}$, and Lactobacillus fermentum 5007 (CGMCC 1.3223) was used as negative control because it was previously confirmed to have no FAE activity. After incubation, we observed whether a clear zone formed around the suspension. If a clear zone appeared on the MRS plates, this indicated that the strain L. fermentum 17SD-2 had FAE activity.

\section{Morphological, physiological, and biochemical characteristics of Lactobacillus fermentum} 17SD-2

Gram staining and catalase activity of L. fermentum 17SD-2 were determined after $24 \mathrm{~h}$ of incubation on MRS agar or broth. To measure the growth curve of Lactobacillus fermentum 17SD2 , the bacterial cells at a density of $1 \times 10^{7} \mathrm{CFUs} / \mathrm{ml}$ were seeded in MRS broth. The absorbance of Lactobacillus fermentum 17SD-2 culture at $600 \mathrm{~nm}$ were regularly monitored with a microplate reader. To evaluate salt tolerance, $2 \%$ culture was inoculated into MRS broth containing $3.0 \%$ and $6.5 \% \mathrm{NaCl}$, and then cultured at $37^{\circ} \mathrm{C}$ for 24 hours. To evaluate acid tolerance, $2 \%$ culture was inoculated into MRS broth with $\mathrm{pH} 3.5,4.0,4.5,8.0,8.5$, and 9.0, and then cultured at $37^{\circ} \mathrm{C}$ for 24 hours. To evaluate temperature tolerance, $2 \%$ culture was inoculated into MRS broth, and then cultured at different temperatures (including $15,20,25,30,35,40$, and $45^{\circ} \mathrm{C}$ ) for 24 hours. Then 
107

108

109

110

111

112

113

114

115

116

117

the absorbance of Lactobacillus fermentum 17SD-2 cultures at $600 \mathrm{~nm}$ was measured with a microplate reader. The value of $\mathrm{OD}_{600}$ greater than 0.3 was considered as positive, expressed with “+”. API 50CH contains a high level of carbohydrates and was used to determine carbon source utilization according to the manufacturer instructions.

\section{Alfalfa harvest and silage preparation}

Alfalfa at blooming stage was manually harvested from an experimental field with an area of 5 $\mathrm{m} \times 10 \mathrm{~m}$, located at the Wuqing District $\left(117^{\circ} 10^{\prime} \mathrm{E}, 39^{\circ} 10^{\prime} \mathrm{N}\right)$, Tianjin, China on June $7^{\text {th }}, 2018$. At first, the harvested alfalfa was divided into two groups: fresh (sample1, S1) and wilted (sample 2 , S2, wilted in the field for 5 hours). Alfalfa with various dry matter (DM) contents (S1: 23.82\%; S2: $29.63 \%$ ) was directly chopped into pieces in length of 2-3 cm using a crop chopper.

A commercial CE (10,000 U/g; Macklin Biochemical Co., Ltd; Shanghai; China) and $L$. fermentum 17SD-2 were used as additives for silage making. L. fermentum 17SD-2 could grow well at low $\mathrm{pH}$ conditions and possess high FAE-activity (clear zone with a diameter of $11.3 \mathrm{~mm}$ ). The inoculant was added at a level of $10^{6}$ colony forming unit (CFU) per gram of fresh matter (FM). CE was applied at a ratio of $1 \mathrm{~g} \mathrm{~kg}^{-1}$ of FM (Chen et al., 2017).

The experimental treatments were designed as follows. Each group (sample 1 and sample 2) included 12 piles (500 g per pile), and they were randomly ensiled with four additives treatments: (i) untreated control (CK); (ii) application of commercial cellulase (CE); (iii) application of $L$. fermentum 17SD-2 (LF); and (iv) combination of L. fermentum 17SD-2 and commercial CE $(\mathrm{LF}+\mathrm{CE})$. Then, chopped material was mixed homogenously with the additives and packed manually into $35 \mathrm{~cm} \times 50 \mathrm{~cm}$ polyethylene bags which were tightly vacuumed, and triplicates for per treatment were prepared. A total of 24 bags ( 2 groups $\times 4$ treatments $\times 3$ replicates $)$ were kept at ambient temperature $\left(21-30^{\circ} \mathrm{C}\right)$. After 60 days of ensiling, three bags per treatment were opened to evaluate their fermentation end products, chemical composition, and microbial communities.

\section{Microorganism and fermentation quality analysis}

To evaluate microbial counts, $10 \mathrm{~g}$ forage (raw materials and silage) was extracted with $90 \mathrm{~mL}$ $0.85 \%$ sterile physiological saline solution, and serially diluted from $10^{-1}$ to $10^{-6}$. In total, $100 \mu \mathrm{L}$ from an appropriate dilution was spread on agar plates. Lactic acid bacteria were enumerated on MRS agar after incubation at $30^{\circ} \mathrm{C}$ for $72 \mathrm{~h}$. Molds and yeasts were counted on potato dextrose agar (Nissui) after incubation at $28^{\circ} \mathrm{C}$ for $24 \mathrm{~h}$, and yeasts were distinguished from molds or other bacteria by colony appearance and cell morphology observation (Avila et al., 2009). Plates containing a minimum of 30 and a maximum of 300 colony-forming units were enumerated (Reich $\&$ Kung, 2010). To determine the fermentation parameters, the sample (25 g) was mixed with 225 
$142 \mathrm{~mL}$ sterile water and incubated at $4{ }^{\circ} \mathrm{C}$ overnight and then filtered through four layers of

143

144

145

146

147

148

149

150

151

152

153

154

155

156

157

158

159

160

161

162

163

164

165

166

167

168

169

170

171

172

173

174

175

176

177 cheesecloth (Touno et al., 2014). The filtrate was used to measure $\mathrm{pH}$ and the concentrations of ammonia-N and organic acid. The ammonia-N content was determined according to phenolhypochlorite and ninhydrin colorimetric procedures described in a previous study (Broderick \& Kang, 1980). Organic acids were analyzed using high-performance liquid chromatography (HPLC), equipped with a UV detector and set as follows: ICSep COREGEL-87H column, eluent $5 \mathrm{mmol} / \mathrm{L} \mathrm{H}_{2} \mathrm{SO}_{4}$ with a running rate of $0.6 \mathrm{~mL} / \mathrm{min}$, temperature of column oven $50^{\circ} \mathrm{C}$, injection volume of $10 \mu \mathrm{L}$.

\section{Analysis of chemical composition}

To determine the DM content, the samples were dried in a forced-air oven at $65^{\circ} \mathrm{C}$ for $48 \mathrm{~h}$ and then dried at $103^{\circ} \mathrm{C}$ to constant weight. The silage DM losses during drying were calculated according to the formula of Porter, Steen et al (1995). Dried sample was grinded to $1.0 \mathrm{~mm}$ particle diameter. The WSC was determined using the anthrone method (Murphy, 1958) and the CP was analyzed according to the standard procedure detailed by the Association of Official Analytical Chemists (AOAC, 1990). The content of NDF and ADF were measured according to the method described in a previous study (Van Soest et al., 1991).

\section{Bacterial diversity analysis}

Samples (20 g) were mixed with $180 \mathrm{~mL}$ of sterile $0.85 \% \mathrm{NaCl}$ solution with vigorous shaking at $120 \mathrm{r} / \mathrm{m}$ for $2 \mathrm{~h}$. The mixture was filtered through four layers cheesecloth and the filtrate was centrifuged at $10,000 \mathrm{r} / \mathrm{m}$ for $10 \mathrm{~min}$ at $4^{\circ} \mathrm{C}$. The deposit was resuspended in $1 \mathrm{~mL}$ of sterile $0.85 \%$ $\mathrm{NaCl}$ solution and the microbial pellets were obtained by centrifugation at $12,000 \mathrm{r} / \mathrm{m}$ for $10 \mathrm{~min}$ at $4^{\circ} \mathrm{C}$. To extract total DNA in raw material and silage samples (30 samples in total), the DNA Easy Power Soil Kit (QIAGEN, GREMANY) was used according to the manufacture's protocols. The PCR reactions were conducted in a $20 \mu \mathrm{L}$ mixture $(10 \mathrm{ng}$ of template DNA, $2 \mu \mathrm{L}$ of $2.5 \mathrm{mM}$ dNTPs, $0.8 \mu \mathrm{L}$ of each primer $(5 \mu \mathrm{M}), 0.4 \mu \mathrm{L}$ of FastPfu Polymerase, and $4 \mu \mathrm{L}$ of $5 \times$ FastPfu Buffer, $0.2 \mu \mathrm{L}$ of BSA, $11.8 \mu \mathrm{l}$ of $\mathrm{ddH}_{2} \mathrm{O}$ ). According to Ni et al. (2017), the 16S rDNA V3-V4 regions were amplified using primers 338F (ACTCCTACGGGAGGCAGCAG) and 806R (GGACTACHVGGGTWTCTAAT). Triplicate PCR reaction for each sample was conducted to minimize PCR deviation, and a mixture of the three PCR products was sequenced.

\section{High-throughput sequencing and bacterial diversity analysis}

Amplicons were extracted from $2 \%$ agarose gels, purified with a Qiagen Gel Extraction Kit (Qiagen, Germany) and sequenced at Shanghai Majorbio Bio-pharm Technology Co., Ltd using paired-end sequencing $(2 \times 300 \mathrm{bp})$ with an Illumina MiSeq platform according to 
the standard protocols. Raw tags were quality-filtered by Trimmomatic (Version 3.29) and merged by FLASH (Version 1.2.7) with the following criteria: (i) the reads were truncated at any site receiving an average quality score $<20$ over a 50 bp sliding window; (ii) sequences with overlaps longer than $10 \mathrm{bp}$ were merged according to their overlap with mismatches no more than $2 \mathrm{bp}$; and (iii) sequences of each sample were separated according to barcodes (exactly matching) and primers (allowing 2 nucleotides mismatching) and reads containing ambiguous bases were removed. Operational taxonomic units (OTUs) were clustered with 97\% similarity using UPARSE (version $7.1 \mathrm{http}: / /$ drive5.com/uparse/). OTUs were used to calculate rarefaction and alpha diversity (Mothur (v.1.30.1).

\section{Statistical Analysis}

Data shown are means \pm standard deviation (SD). All microbial counts data were converted to $\log 10$ and the results were described on a fresh weight basis. Two-way analysis of variance was used to evaluate the effects of water contents, additives and their interaction on microbial population, $\mathrm{pH}$ values, fermentation characteristic, chemical composition and alpha diversity of bacterial community in alfalfa silage. All the statistical analyses were performed using the general linear model procedure of SAS (version 9.0, SAS Institute, Cary, NC, USA, 2002). The means were compared for significance by Duncan's multiple range method and the significance was declared at $P<0.05$.

\section{RESULTS}

\section{Chemical and microbial composition of raw materials and the characteristics of} Lactobacillus fermentum 17SD-2

The chemical composition and microbial populations of the alfalfa crops before ensiling are shown in Table 1 . The DM contents of sample 1 and sample 2 were $23.82 \%$ and $29.63 \%$ of FM, respectively; their CP contents were 22.63 and 25.34\% DM, respectively; and NDF and ADF concentrations were $33.3-38.3 \%$ and $25.5-29.7 \%$ DM, respectively. In this study, the WSC contents were lower than $1.8 \%$ of DM in both samples. Additionally, the numbers of epiphytic $\mathrm{LAB}$, yeast, and mold were similar between sample 1 and sample 2 . The count of LAB was lower than $10^{3} \mathrm{CFU} / \mathrm{g}$ FM, while yeast and mold counts were around $10^{4} \mathrm{CFU} / \mathrm{g}$ FM.

The characteristics of the selected LAB are shown in Table 2. L. fermentum 17SD-2 is Grampositive, heterofermentation and catalase-negative and was able to grow at a wide range of $\mathrm{pH}(\mathrm{pH}$ $3.5-9.0)$, a broad range temperature $\left(15-45^{\circ} \mathrm{C}\right)$, and a salinity of $6.5 \%$. L. fermentum $17 \mathrm{SD}-2$ used the following as carbon sources: ribose, galactose, D-glucose, D-fructose, D-mannose, maltose, lactose, melibiose, sucrose, D-raffinose, gluconate, and 5-keto-gluconate. Furthermore, this strain grew vigorously and possessed high FAE activity (Figure 1). 
215

216

217

218

219

220

221

222

223

224

225

226

227

228

229

230

231

232

233

234

235

236

237

238

239

240

241

242

243

244

245

246

247

248

249

250

\section{Effects of CE, $\mathrm{LF}$, and $\mathrm{LF}+\mathrm{CE}$ on the $\mathrm{pH}$ values and microbial characteristics of alfalfa silage}

The final $\mathrm{pH}$ values and microbial populations of sample 1 and sample 2 were similar after ensiling (Table 3). Mold was not detected in all silage, and the significance analysis of main factors revealed that all additives $(\mathrm{CE}, \mathrm{LF}$, and $\mathrm{CE}+\mathrm{LF})$ significantly increased the $\mathrm{LAB}(P<0.001)$ numbers, but decreased the yeast $(P<0.001)$ numbers. All treatments had lower $(P<0.001) \mathrm{pH}$ values than those of control, particularly the lowest $\mathrm{pH}$ (4.6-4.7) in LF+CE treatments, which was much lower than the addition of CE or LF alone.

\section{Effects of CE, LF, and $\mathrm{LF}+\mathrm{CE}$ on the fermentation quality and chemical composition of alfalfa silage}

The fermentation parameters and chemical composition of the alfalfa silage after 60 days of ensiling are shown in Table 4. Lactic acid and acetic acid emerged as the main fermentation end products in all alfalfa silage. All additives remarkably increased the lactic acid content $(P<0.001)$, in particular, $\mathrm{LF}+\mathrm{CE}$ had a significant effect on lactic acid and butyric acid content. All treatments had higher lactic acid content and ratio of lactic acid and acetic acid, and LF+CE treatments had the highest lactic acid contents. In this study, all treated silage, especially LF+CE silage, had a lower level of butyric acid content $(<1.0 \% \mathrm{DM})$, while a large amount of butyric acid (about $2.63 \% \mathrm{DM}$ ) appeared in the control silage of sample 1. In sample 2, no great difference was observed between control and additive treatments (except for $\mathrm{LF}+\mathrm{CE}$ treatment).

Although all additives decreased ammonia-N $(P<0.001)$ and increased CP $(P<0.001)$ contents compared to control, the $\mathrm{LF}+\mathrm{CE}$ treated silage had the highest contents of CP and lowest ammonia$\mathrm{N}$. Compared with the addition of CE alone, lower NDF and ADF contents were found in LF+CE treatment. Overall, the silage treated with FAE-producing LAB plus cellulase was better than those of the silage treated with either LAB or cellulase alone.

\section{Effects of CE, $\mathrm{LF}$, and $\mathrm{LF}+\mathrm{CE}$ on microbial communities after 60 days of ensiling}

High-throughput sequencing of $16 \mathrm{~S}$ rRNA gene amplicons was conducted to systematically describe the bacterial communities in the raw material and silage. Alpha diversity of all samples is shown in Table 5. The coverage of all samples was above 0.99 , which indicated that the sampling depth adequately captured most of the bacteria. Compared with sample 1, lower Chao and Shannon indexes were observed in sample 2, which was consistent with the results reported by Wang et al (2018), indicated that wilting (water content) had an important influence on silage microorganism. Lower observed species than pre-ensiled alfalfa crops and that of control appeared in CE alone or with LF treated silage in sample 2. In contrast, in sample 1, observed species in LF and LF+CE treated silages were higher, especially in LF treatment. Although we could not classify the behind reason clearly, probably related to the high number of the epiphytic detrimental microorganisms. 
251

252

253

254

255

256

257

258

259

260

261

262

263

264

265

266

267

268

269

270

271

272

273

274

275

276

277

278

279

280

281

282

283

284

285

286

The dynamic variance of microbial population with different treatments can be demonstrated by principle co-ordinates analysis (PCoA). As shown in Figure 2A (sample 1), component 1 and component 2 could explain $58.07 \%$ and $28.51 \%$ of the total variance, respectively; Similarity, in figure 2B (sample 1), component 1 and component 2 could explain 50.94\% and $41 \%$, respectively. Basically, Raw materials S1 and S2 could be well separated from all silage samples, indicating that ensiling was the main factor affecting anaerobic fermentation. Among silage samples, the distance between $\mathrm{CK}$ and CE treatments was near, similar phenomenon was observed between LF and $\mathrm{LF}+\mathrm{CE}$ treatments, indicated that the addition of L. fermentum 17SD-2 had a significant effect on bacterial community in alfalfa silage. In addition, the variation in microbial community might be one critical factor leading to difference in silage quality.

The bacterial communities at the genus level of all alfalfa silage before and after 60 days of ensiling are shown in Figure 2C and 2D. Before ensiling, in both raw materials (S1 and S2), Cyanobacteria and Pantoea were the most abundant genera, above $53.86 \%$ and $8.33 \%$ of the entire community, respectively. However, after fermentation, the high abundance of Cyanobacteria and Pantoea significantly decreased or even disappeared. Enterobacter and Lactobacillus gradually became the most prevalent genera. Although Enterobacter was detected in all silage, their relative abundance decreased from $49.98 \%$ to $17.01 \%$ with the addition of LF and CE, furthermore, LF alone or with CE treated silage showed much lower Enterobacter abundance than control and CE alone treatment. In addition, a similar phenomenon was observed in sample 2.

Lactobacillus, a desirable genus, was present in all silage and Lactobacillus was highly abundant in $\mathrm{LF}$ or LF+CE-treated silage, especially in sample 2, where this genus accounted for $85.36 \%$ and $85.50 \%$ of the total community, respectively. Many other LAB genera, i.e., Pediococcus, Enterococcus, Weissella, and Lactococcus, were also detected after ensiling. For example, in sample 2 silage, the proportions of Pediococcus and Enterococcus ranged from $10.15 \%$ to $1.26 \%$ and $11.35 \%$ to $<0.1 \%$, respectively. Weissella and Lactococcus were mainly detected in control and CE treatment. Additionally, relatively high proportions of Anaerosporobacter (5.96\%), Clostridium (4.78\%), and Garciella (3.65\%) were observed in the control of sample 1.

\section{Relationship between main genera and silage quality}

To better understand the relationships between bacterial compositions and silage properties, a Spearman correlation heatmap was constructed at the genus level (Figure 3). Spearman correlation analysis illustrated that Lactobacillus was positively correlated with LA/AA $(r=0.47)$, DM $(r=$ $0.69)$, and $\mathrm{CP}(\mathrm{r}=0.71)$ contents, while it was negatively correlated with concentration of ammonia-N $(\mathrm{r}=-0.81)$ and $\mathrm{pH}(\mathrm{r}=-0.47)$. Enterococcus and Weissella were negatively correlated with LA/AA $(\mathrm{r}=-0.65$ and -0.51$)$ and positively with $\mathrm{pH}(\mathrm{r}=0.64$ and 0.51$)$ and ammonia-N $(\mathrm{r}$ $=0.75$ and 0.75$)$. Enterobacter was positively correlated with the concentration of ammonia-N (r 
287

288

289

290

291

292

293

294

295

296

297

298

299

300

301

302

303

304

305

306

307

308

309

310

311

312

313

314

315

316

317

318

319

320

321

322

$=0.47)$, but was negatively correlated with $\mathrm{CP}(\mathrm{r}=-0.47)$ content.

\section{DISCUSSION}

Although ensiling is considered an effective method for preserving high moisture forage, it has shown some limitations in the production of high-quality alfalfa silage due to its low WSC content and high buffering capacity. During the ensiling process, the epiphytic LAB naturally present on forage crops are responsible for silage fermentation and also influence silage quality, which mainly transforms WSC into organic acids, primarily lactic acid, to inhibit the activity of undesirable bacteria. However, in the present study, low WSC contents (below $1.80 \% \mathrm{DM}$ ), a low number of epiphytic LAB $\left(<10^{3} \mathrm{CFU} / \mathrm{g}\right.$ of $\left.\mathrm{FM}\right)$ and high buffering capacity may lead to unsatisfactory preservation. Therefore, the ensiling process should be regulated by additions such as cellulase and LAB. In the present study, the selected Lactobacillus fermentum 17SD-2 strain grew well at low $\mathrm{pH}$ and it could grow at road temperature. Additionally, this strain grows vigorously and has high FAE activity.

FAE, an important auxiliary enzyme, plays an essential role in plant cell wall hydrolysis by breaking the ester-linked bond between cell wall phenolic acids and polysaccharides, which makes the plant cell wall more accessible to enzyme attack (Faulds et al., 2011). Recently, researchers have increasingly reported that most commercial enzyme additives are already mixtures of several fibrolytic enzymes and the effect of these additives on silage chemical composition is actually an integrated effect of synergistic interactions (Li et al., 2018; Li et al., 2014).

As expected, in the current study, compared with addition of CE alone, lower NDF and ADF contents were found in FAE-producing L. fermentum 17SD-2 and cellulase (LF+CE) treatment, and a similar result was found in mixed small-grain silage (Jin et al., 2017). These results indicated that the combination of LF and CE might have a synergistic effect, while whether the fiber degradation rate in vivo is higher in $\mathrm{LF}+\mathrm{CE}$ group than the other two (LF and CE) groups need further research. However, it has been reported that the use of an enzyme product in combination with a FAE-producing inoculant did not improve corn silage fermentation or its nutritive value (Lynch et al., 2015). This discrepancy might be caused by the abundantly epiphytic LAB population of corn compared to alfalfa, resulting in inoculated FAE-producing LAB not dominating the epiphytic microbial population at the ensiling process of corn.

The $\mathrm{pH}$ value is considered an important indicator reflecting microbial activity and silage fermentation. In this study, all treatments had lower $\mathrm{pH}$ values but higher lactic acid content than those of control. The relatively lower $\mathrm{pH}$ value and higher content of lactic acid in the $\mathrm{CE}$ and $\mathrm{LF}+\mathrm{CE}$-treated silage, especially the $\mathrm{pH}$ values in $\mathrm{LF}+\mathrm{CE}$, declined to around 4.6-4.7, much lower $(P<0.05)$ than that of the addition of CE or LF alone, which could be due to the direct increase of the fermentable substrate through degrading the plant cell wall. All treated silage had a higher ratio 
323 of lactic acid and acetic acid, which might indicate that the silage fermentation of alfalfa can be

324

325

326

327

328

329

330

331

332

333

334

335

336

337

338

339

340

341

342

343

344

345

346

347

348

349

350

351

352

353

354

355

356

357

358 driven towards a homo-fermentative model with the addition of CE and LF.

Additionally, for well-preserved silage, butyric acid content is less than 1.0\% DM (McDonald et al., 1991) and is usually produced by Clostridia. For instance, in sample 1 silage, all treatments, especially $\mathrm{LF}+\mathrm{CE}$ treatment, had a lower level of butyric acid content $(<1.0 \% \mathrm{DM})$. Control silage had unsatisfactory preservation due to low content of lactic acid, high $\mathrm{pH}$, and high content of butyric acid and ammonia-N together with high abundance of Clostridium, Anaerosporobacter, and Garciella (Figure 2C). These bacteria are obligate anaerobes from the class Clostridia. Clostridia is an influential component of bacterial communities and is often detected in grass silages. The appearance of Clostridia is undesirable because they can take advantage of protein and water soluble carbohydrate to produce butyric acid and consequently affect silage quality due to unpleasant odor (Zheng et al., 2017). That may help explain the poor fermentation quality in the control of sample 1, which was consistent with the report by Nishino et al. (2012). However, a similar result was not observed in sample 2 silage, which was possibly because high DM content could efficiently inhibit the growth of Clostridium.

The ammonia-N level reflects the $\mathrm{CP}$ degradation in silage, which is an important criterion for evaluating silage quality. Although all additives decreased ammonia- $\mathrm{N}$ but increased $\mathrm{CP}$ content compared with those of control, especially, the LF+CE treated silage had the highest content of $\mathrm{CP}$ and lowest ammonia-N, and similar results were also found in Stylo silage produced using a mixture of LAB and cellulase ( $\mathrm{Li}$ et al., 2017). The most plausible reason was that the $\mathrm{LF}+\mathrm{CE}$ addition could efficiently inhibit the growth of undesirable proteolytic bacteria, such as Enterobacter. Enterobacter is generally considered undesirable during the ensiling process, because it can ferment lactic acid to acetic acid and other products, thus subsequently causing nutrition loss (Ni et al., 2017). In this study, although Enterobacter was detected in all silage, their relative abundance was much lower in the $\mathrm{LF}$ and $\mathrm{LF}+\mathrm{CE}$ treated silage. In contrast, desirable LAB such as Lactobacillus, Enterococcus, Pediococcus, and Weissella, rod-shaped Lactobacillus plays a critical role in enhancing lactic acid content and reducing pH value (Cai et al., 1998). In the present study, Lactobacillus was the most abundant genus in LF or LF+CE treated silage, which might account for their relatively high fermentation quality.

\section{CONCLUSION}

Compared with addition of CE or LF alone, inoculation of a FAE-producing lactic acid bacteria in combination with cellulase not only improved the silage fermentation quality of alfalfa, but also inhibited the growth of undesirable microbes. Silage inoculants consisting of FAE-producing LAB might be an effective way to improve the silage quality of alfalfa 
359

360

361

362

363

364

365

366

367

368

369

370

371

372

373

374

375

376

377

378

379

380

381

382

383

384

385

386

387

388

389

390

391

392

393

394

\section{ADDITIONAL INFORMATION AND DECLARATIONS}

\section{Funding}

This work was supported by grants from the Special Fund for Agro-scientific Research in the Public Interest (201503134) and the National Natural Science Foundation of China (31570114). The funders had no role in study design, data collection and analysis, decision to publish, or preparation of the manuscript.

\section{Competing Interests}
All authors declare no competing interests.

\section{Author contributions}

- Rina Su conceived, designed and performed the experiments, analyzed the data, contributed reagents/materials/analysis tools, prepared figures and/or tables, authored or reviewed drafts of the paper, approved the final draft.

- Kuikui $\mathrm{Ni}$ conceived, designed the experiments, analyzed the data, contributed reagents/materials/analysis tools, prepared figures and/or tables, authored or reviewed drafts of the paper, approved the final draft.

- Tianwei Wang analyzed the data, contributed reagents/materials/analysis tools, prepared figures and/or tables, authored or reviewed drafts of the paper, approved the final draft.

- Xiaopan Yang analyzed the data, contributed reagents/materials/analysis tools, prepared figures and/or tables, authored or reviewed drafts of the paper, approved the final draft, analyzed the data on fermentation quality after ensiling.

- Jie Zhang analyzed the data, contributed reagents/materials/analysis tools, prepared figures and/or tables, authored or reviewed drafts of the paper, approved the final draft, analyzed the data on chemical composition after ensiling.

- Yayong Liu approved the final draft, examined the spelling errors and grammatical errors.

- Weixiong Shi performed the experiments and approved the final draft.

- Yan Liu performed the experiments.

- Jie Chen performed the experiments.

- Jin Zhong conceived, designed experiments, analyzed the data, authored or reviewed drafts of the paper, approved the final draft.

\section{REFERENCES}

Addah, W., Baah, J., Okine, E. K., \& McAllister, T. A. (2012). A third-generation esterase inoculant alters fermentation pattern and improves aerobic stability of barley silage and 
395

396

397

398

399

400

401

402

403

404

405

406

407

408

409

410

411

412

413

414

415

416

417

418

419

420

421

422

423

424

425

426

427

428

429

430

the efficiency of body weight gain of growing feedlot cattle. J Anim Sci, 90(5), 15411552. doi:10.2527/jas.2011-4085

AOAC. (1990). Official Methods of Analysis, 15th ed. Association of Official Analytical Chemists, Arlington, VA.

Avila, C. L. S., Pinto, J. C., Figueiredo, H. C. P., \& Schwan, R. F. (2009). Effects of an indigenous and a commercial Lactobacillus buchneri strain on quality of sugar cane silage. Grass and Forage Science, 64, 384-394. doi:10.1111/j.1365-2494.2009.00703.x

Broderick, G. A., \& Kang, J. H. (1980). Automated simultaneous determination of ammonia and total amino acids in ruminal fluid and In vitro media. J Dairy Sci, 63, 64-75.

Cai, Y., Benno, Y., Ogawa, M., Ohmomo, S., Kumai, S., \& Nakase, T. (1998). Influence of Lactobacillus spp. from an inoculant and of Weissella and Leuconostoc spp. from forage crops on silage fermentation. APPl. Environ. Microb, 64, 2982-2987.

Chen, X., Li, W., Gao, C., Zhang, X., Weng, B., \& Cai, Y. (2017). Silage preparation and fermentation quality of kudzu, sugarcane top and their mixture treated with lactic acid bacteria, molasses and cellulase. Anim Sci J, 88(11), 1715-1721. doi:10.1111/asj.12840

Faulds, C. B., Molina, R., Gonzalez, R., Husband, F., Juge, N., Sanz-Aparicio, J., \& Hermoso, J. A. (2005). Probing the determinants of substrate specificity of a feruloyl esterase, AnFaeA, from Aspergillus niger. FEBS J, 272(17), 4362-4371. doi:10.1111/j.17424658.2005.04849.x

Faulds, C B., Perez-Boada, M., Martinez, A T. (2011). Influence of organic co-solvents on the activity and substrate specificity of feruloyl esterases[J]. Bioresour Technol, 102, (8): 4962-4967.

Fritsch, C., Jansch, A., Ehrmann, M. A., Toelstede, S., \& Vogel, R. F. (2017). Characterization of Cinnamoyl Esterases from Different Lactobacilli and Bifidobacteria. Curr Microbiol, 74(2), 247-256. doi:10.1007/s00284-016-1182-x

Gulfam, A., Guo, G., Tajebe, S., Chen, L., Liu, Q., Yuan, X., . . Saho, T. (2017). Characteristics of lactic acid bacteria isolates and their effect on the fermentation quality of Napier grass silage at three high temperatures. $J$ Sci Food Agric, 97(6), 1931-1938. doi:10.1002/jsfa.7998

Jin, L., Dunière, L., Lynch, J. P., Zaheer, R., Turkington, K., Blackshaw, R. E., . . Wang, Y. (2017). Impact of ferulic acid esterase-producing lactobacilli and fibrolytic enzymes on ensiling and digestion kinetics of mixed small-grain silage. Grass and Forage Science, 72(1), 80-92. doi:10.1111/gfs. 12217

Kang, T. W., Adesogan, A. T., Kim, S. C., \& Lee, S. S. (2009). Effects of an esterase-producing inoculant on fermentation, aerobic stability, and neutral detergent fiber digestibility of corn silage. J Dairy Sci, 92(2), 732-738. doi:10.3168/jds.2007-0780 
431

432

433

434

435

436

437

438

439

440

441

442

443

444

445

446

447

448

449

450

451

452

453

454

455

456

457

458

459

460

461

462

463

464

465

466

Khota, W., Pholsen, S., Higgs, D., \& Cai, Y. (2016). Natural lactic acid bacteria population of tropical grasses and their fermentation factor analysis of silage prepared with cellulase and inoculant. J Dairy Sci, 99(12), 9768-9781. doi:10.3168/jds.2016-11180

Koseki, T., Fushinobu, S., Ardiansyah; , Shirakawa, H., \& Komai, M. (2009). Occurrence, properties, and applications of feruloyl esterases. Appl Microbiol Biotechnol, 84, 803810. doi:10.1007/s00253-009-2148-8

Li, J., Yuan, X., Dong, Z., Mugabe, W., \& Shao, T. (2018). The effects of fibrolytic enzymes, cellulolytic fungi and bacteria on the fermentation characteristics, structural carbohydrates degradation, and enzymatic conversion yields of Pennisetum sinese silage. Bioresour Technol, 264, 123-130. doi:10.1016/j.biortech.2018.05.059

Li, J., Zhou, P., Liu, H., Xiong, C., Lin, J., Xiao, W., . . Liu, Z. (2014). Synergism of cellulase, xylanase, and pectinase on hydrolyzing sugarcane bagasse resulting from different pretreatment technologies. Bioresour Technol, 155, 258-265. doi:10.1016/j.biortech.2013.12.113

Li, M., Zhou, H., Zi, X., \& Cai, Y. (2017). Silage fermentation and ruminal degradation of stylo prepared with lactic acid bacteria and cellulase. Anim Sci J, 88(10), 1531-1537. doi:10.1111/asj.12795

Li, F., Ding, Z., Ke, W., Xu, D., Zhang, P., Bai, J., . . Guo, X. (2019). Ferulic acid esteraseproducing lactic acid bacteria and cellulase pretreatments of corn stalk silage at two different temperatures: Ensiling characteristics, carbohydrates composition and enzymatic saccharification[J]. Bioresour Technol, 282, 211-221.

Lynch, J. P., Baah, J., \& Beauchemin, K. A. (2015). Conservation, fiber digestibility, and nutritive value of corn harvested at 2 cutting heights and ensiled with fibrolytic enzymes, either alone or with a ferulic acid esterase-producing inoculant. J Dairy Sci, 98(2), 12141224. doi: $10.3168 /$ jds.2014-8768

McDonald, P., Henderson, N., \& Herson, S. (1991). The Biochemistry of Silage. Chalcombe Publications, USA.

Murphy, R. P. (1958). A method for the extraction of plant samples and the determination of total soluble carbohydrates. J. Sci. Food Agric, 9(11), 714-717.

Ni, K., Wang, F., Zhu, B., Yang, J., Zhou, G., Pan, Y., . . Zhong, J. (2017). Effects of lactic acid bacteria and molasses additives on the microbial community and fermentation quality of soybean silage. Bioresour Technol, 238, 706-715. doi:10.1016/j.biortech.2017.04.055

Nishino, N., Li, Y., Wang, C., \& Parvin, S. (2012). Effects of wilting and molasses addition on fermentation and bacterial community in guinea grass silage. Lett Appl Microbiol, 54(3), 175-181. doi:10.1111/j.1472-765X.2011.03191.x

Nsereko, V L., Smiley, B K., Rutherford, W M., Spielbauer, A., Forrester, K J., Hettinger, G H., . 
467

468

469

470

471

472

473

474

475

476

477

478

479

480

481

482

483

484

485

486

487

488

489

490

491

492

. Harman, B R. (2008). Influence of inoculating forage with lactic acid bacterial strains that produce ferulate esterase on ensilage and ruminal degradation of fiber[J]. Animal Feed Science and Technology, 145, 122-135.

Porter, M. G., R. W. J. Steen, D. J. Kilpatrick, F. J. Gordon, C. S. Mayne, R. E. Poots, E. F. Unsworth and C. J. Pippard (1995). Electrometric titration as a method of predicting the chemical composition and corrected dry matter concentration of silage. Animal Feed Science and Technology, 56(3): 217-230.

Reich, L J., \& Kung, L. (2010). Effects of combining Lactobacillus buchneri 40788 with various lactic acid bacteria on the fermentation and aerobic stability of corn silage[J]. Animal Feed Science and Technology, 159, 105-109.

Silva, V. P., Pereira, O. G., Leandro, E. S., Da Silva, T. C., Ribeiro, K. G., Mantovani, H. C., \& Santos, S. A. (2016). Effects of lactic acid bacteria with bacteriocinogenic potential on the fermentation profile and chemical composition of alfalfa silage in tropical conditions. $J$ Dairy Sci, 99(3), 1895-1902. doi:10.3168/jds.2015-9792

Touno, E., Kaneko, M., Uozumi, S., Kawamoto, H., \& Deguchi, S. (2014). Evaluation of feeding value of forage soybean silage as a substitute for wheat bran in sheep. Anim Sci J, 85(1), 46-52. doi:10.1111/asj.12091

Van Soest, P. H., Robertson, J. B., \& Lewis, B. A. (1991). Methods for dietary fiber, neutral detergent fiber, and nonstarch polysaccharides in relation to animal nutrition J Dairy Sci, 74, 3583-3597.

Wang, Y., Wang, C., Zhou, W., Yang, F Y., Chen, X Y., Zhang, Q.(2018). Effects of Wilting and Lactobacillus plantarum Addition on the Fermentation Quality and Microbial Community of Moringa oleifera Leaf Silage[J]. Frontiers in Microbiology, 91817.

Zheng, M. L., Niu, D. Z., Jiang, D., Zuo, S. S., \& Xu, C. C. (2017). Dynamics of microbial community during ensiling direct-cut alfalfa with and without LAB inoculant and sugar. J Appl Microbiol, 122(6), 1456-1470 doi:10.1111/jam.134 
Figure 1

Figure1. Growth curve and plate screening assay showing FAE activity by clear zone around the bacterial suspension.

A, growth curve of Lactobacillus fermentum 17SD-2; B, Lactobacillus fermentum 5007 without FAE activity. C, Lactobacillus fermentum 17SD-2 with FAE activity. 
A

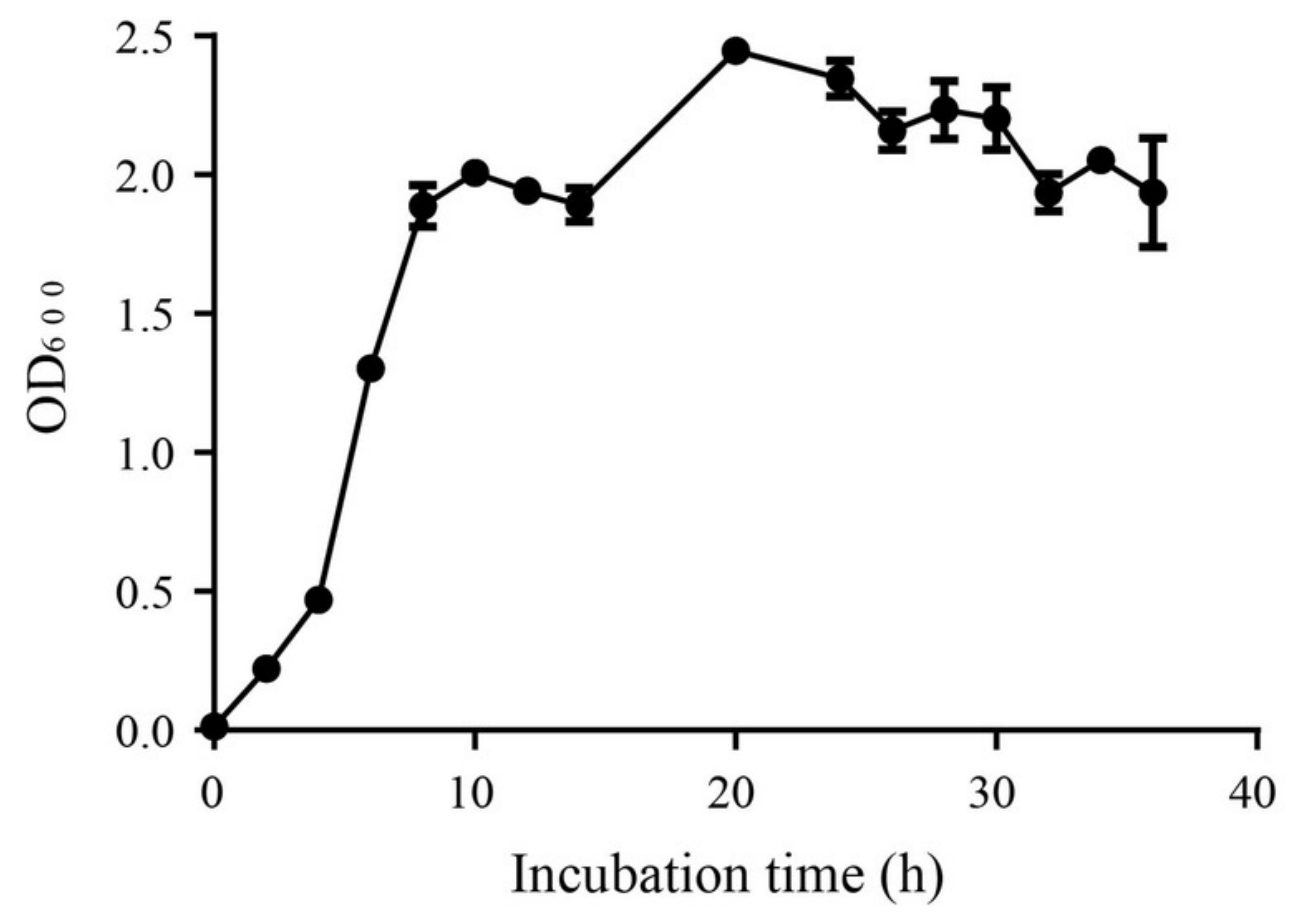

B

C

L. fermentum 5007

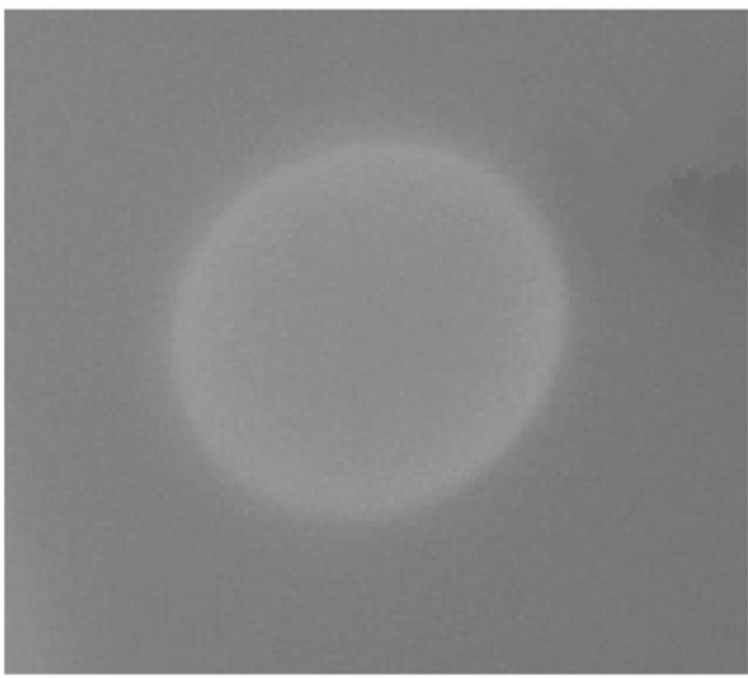

L. fermentum $17 \mathrm{SD}-2$

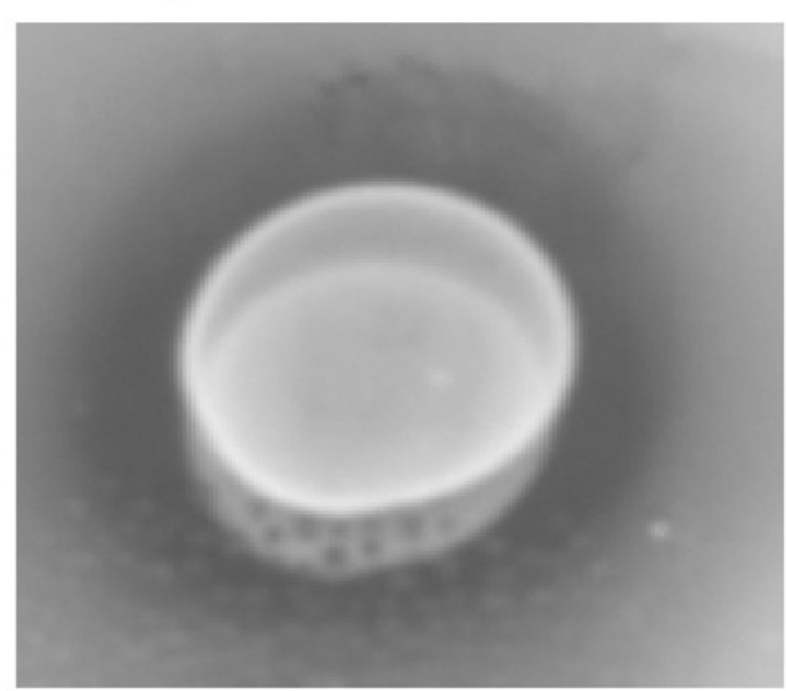




\section{Figure 2}

Figure 2. PCoA analysis and relative abundance of bacterial community at the genus level before and after ensiling.

A, PCoA analysis in sample 1; B. PCoA analysis in sample 2; C. Relative abundances of bacterial composition at genus level in sample 1; D, Relative abundances of bacterial composition at genus level in sample 2. S1, pre-ensiled sample 1; S2, pre-ensiled sample 2;

CK, control (without any additives); CE, cellulase; LF, Lactobacillus fermentum 17SD-2;

LF+CE, combination of Lactobacillus fermentum 17SD-2 and cellulase. 
A

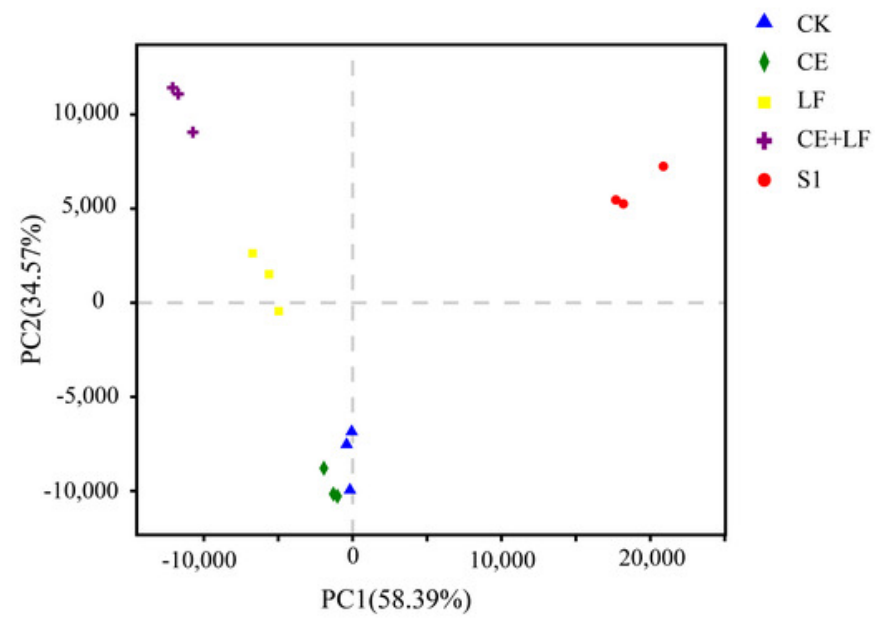

C

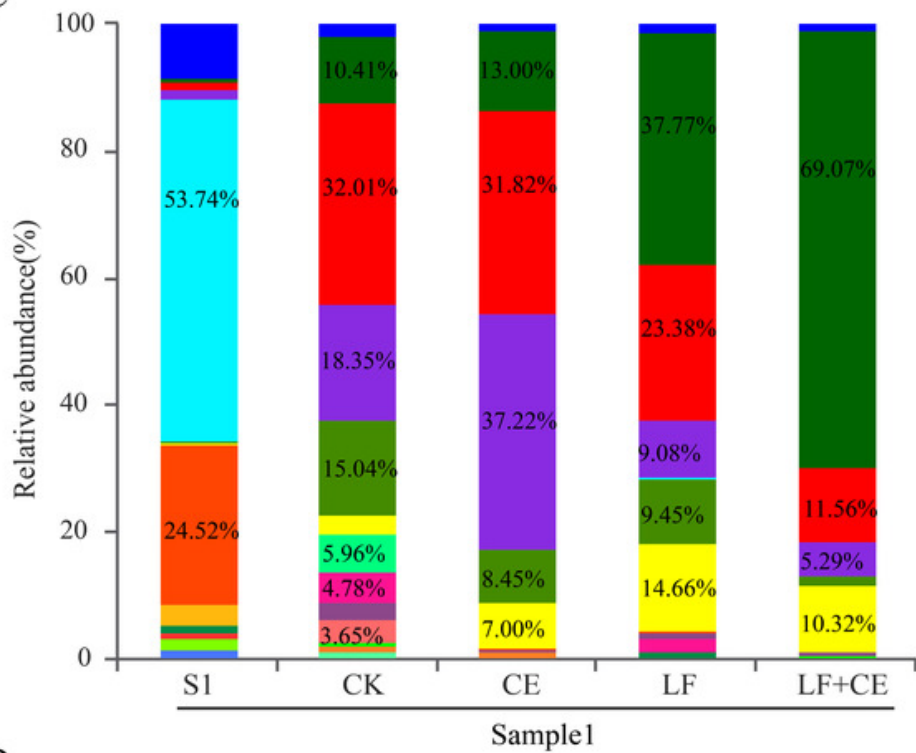

D

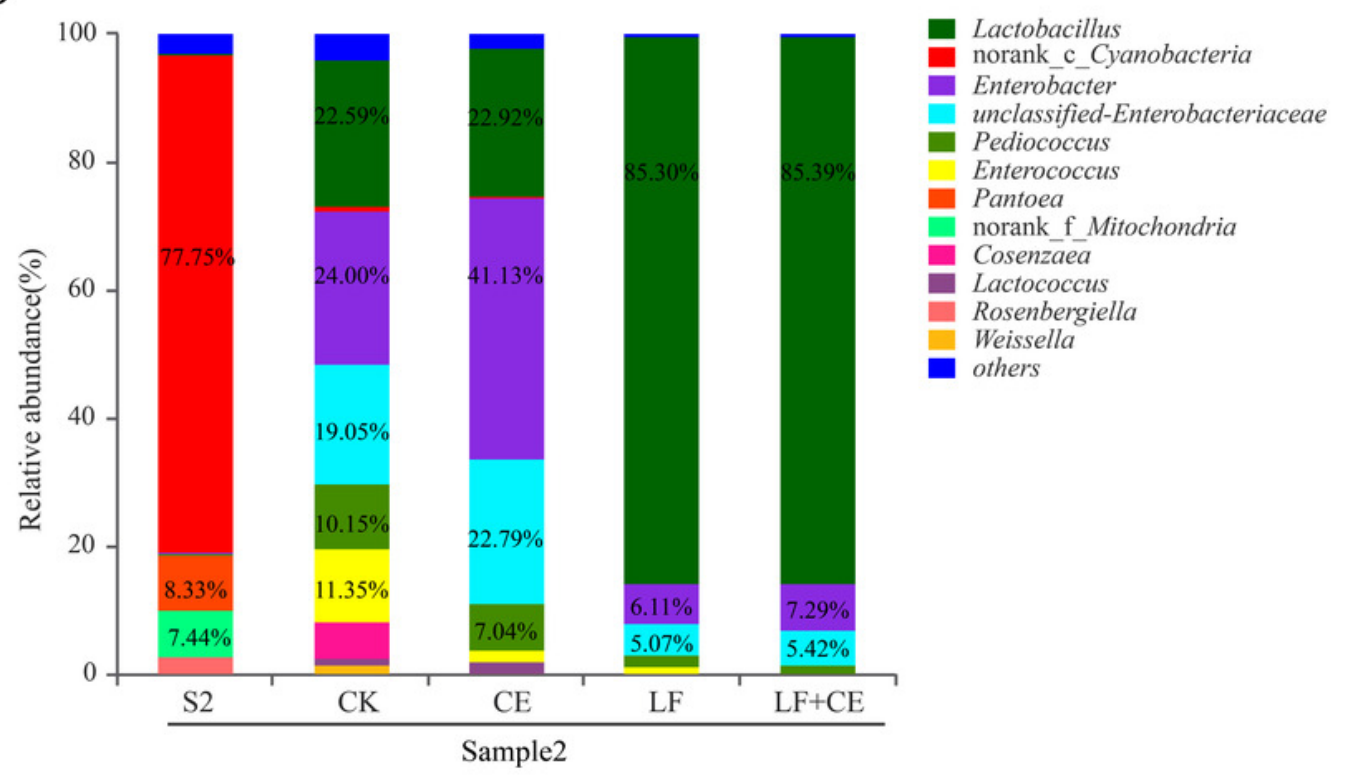

B

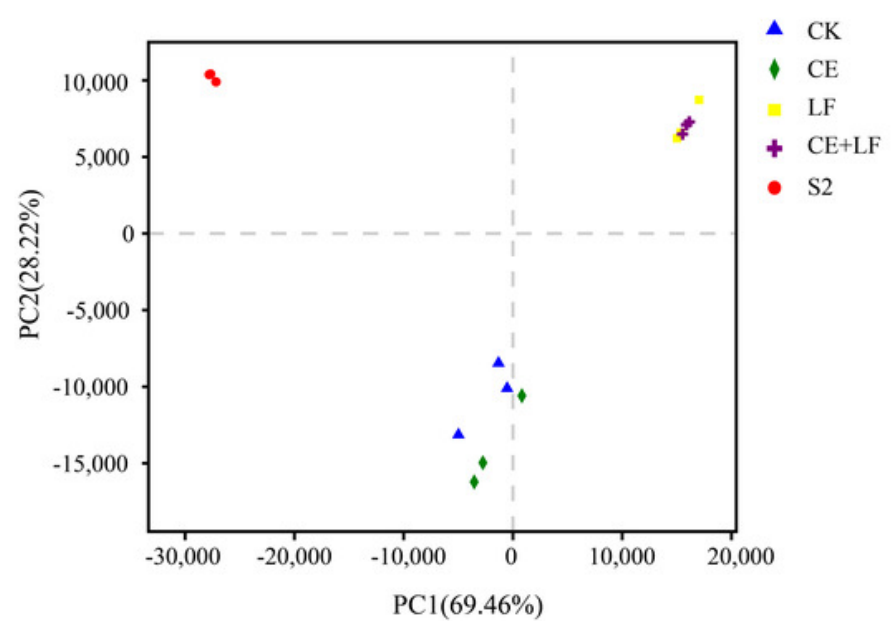

- Lactobacillus

unclassified-Enterobacteriaceae

Enterobacter

norank_c_Cyanobacteria

Enterococcus

Pediococcus

- Pantoea

Anaerosporobacter

Clostridium

- Weissella

Garciella

Exiguobacterium

unclassified-Lactobacillales

Paracoccus

Rhizobium

Planococcus

norank_f_Mitochondria

Mobilitalea

others 
Figure 3

Spearman correlation heatmap between the main genera and silage quality.

$\mathrm{R}$ was presented in different colors; the right side of the legend is the color range of different $R$ values. The value of $P \leq 0.05$ is marked with "*", $P \leq 0.01$ is marked with "**".

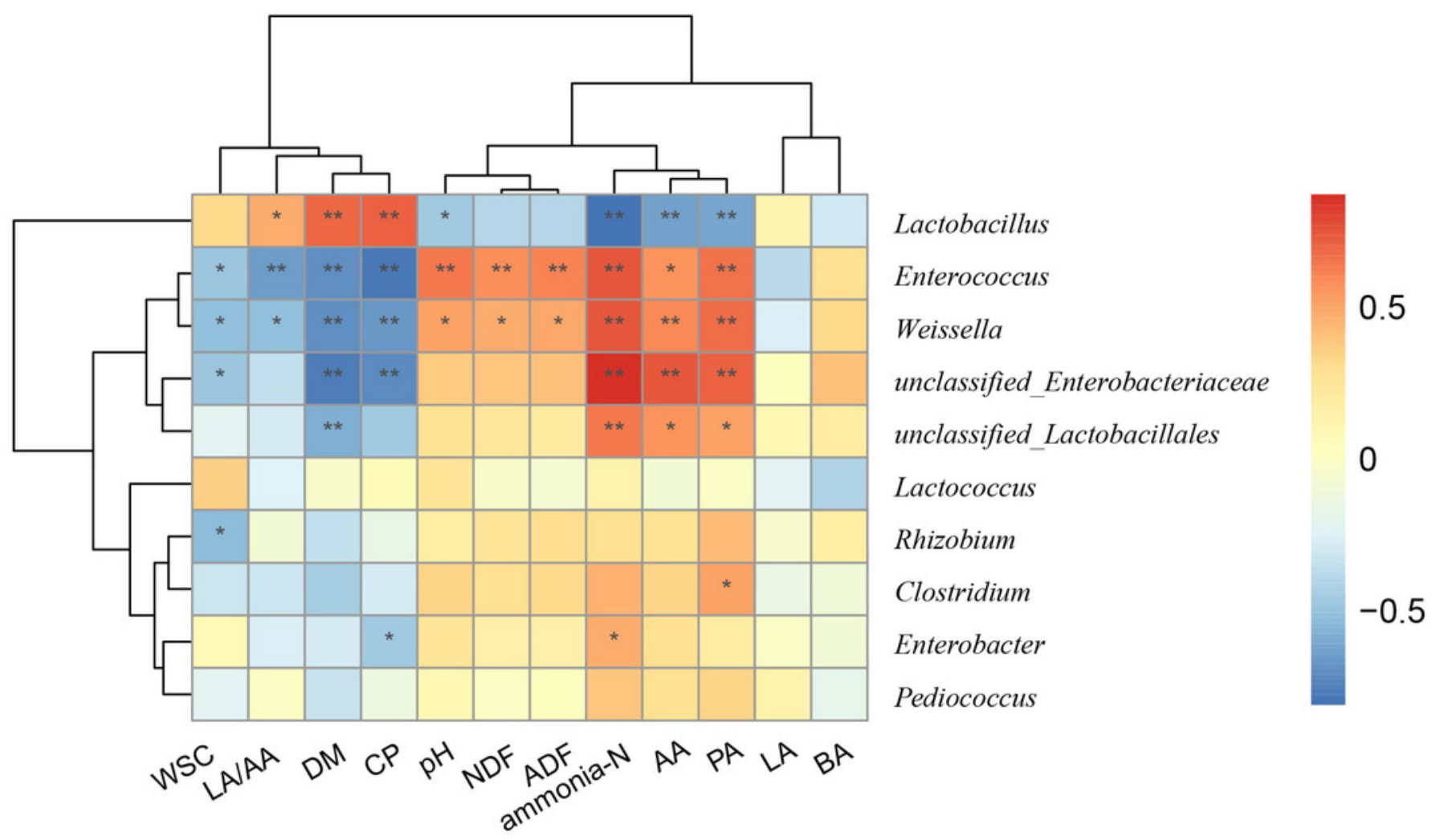




\section{Table $\mathbf{1}$ (on next page)}

Chemical composition, cultivable microbial population and alpha diversity of bacterial community of raw materials before ensiling.

FM, fresh material; DM, dry matter; $C P$, crude protein; NDF, neutral detergent fiber; $A D F$, acid detergent fiber; WSC, water soluble carbohydrates; LAB, lactic acid bacteria, CFU, colony forming units. NA: not applicable. 


\begin{tabular}{llll}
\hline Item & S1 & S2 & $P$ value \\
\hline Chemical composition & & & \\
DM\% & $23.81 \pm 1.12$ & $29.63 \pm 0.53$ & 0.0012 \\
CP (\%DM) & $22.62 \pm 0.35$ & $25.34 \pm 0.21$ & 0.0003 \\
NDF (\%DM) & $38.39 \pm 0.02$ & $33.35 \pm 0.28$ & 0.00001 \\
ADF (\%DM) & $29.73 \pm 0.05$ & $25.54 \pm 0.4$ & 0.0001 \\
WSC (\%DM) & $1.54 \pm 0.12$ & $1.8 \pm 0.05$ & 0.0219 \\
Cultivable microbial population & & & \\
Yeast (log10 cfu/g FM) & $4.38 \pm 0.03$ & $4.08 \pm 0.01$ & 0.00005 \\
Mold (log10 cfu/g FM) & $4.2 \pm 0.01$ & $3.9 \pm 0.12$ & 0.0099 \\
Alpha diversity of bacterial community & & & \\
Observed species & $249.67 \pm 17.21$ & $175 \pm 19.29$ & 0.0075 \\
Shannon & $1.94 \pm 0.46$ & $1 \pm 0.02$ & 0.0244 \\
Simpson & $0.33 \pm 0.05$ & $0.61 \pm 0.02$ & 0.0006 \\
ACE & $327.64 \pm 61.36$ & $262.24 \pm 15.8$ & 0.1483 \\
Chao 1 & $309.88 \pm 28.96$ & $241.81 \pm 7.24$ & 0.0168 \\
Coverage & $>0.99$ & $>0.99$ & NA \\
\hline
\end{tabular}


Table 2 (on next page)

Characteristics of the selected strain Lactobacillus fermentum 17SD-2.

+, positive; -, negative; W, weakly positive. 
1

\begin{tabular}{lc}
\hline Characteristics & Lactobacillus fermentum 17SD-2 \\
\hline Shape & Rod \\
Gram stain & + \\
Fermentation type & - \\
Catalase & \\
Growth at $\mathrm{pH}$ & + \\
3.5 & + \\
4.0 & + \\
4.5 & + \\
8.0 & + \\
8.5 & + \\
9.0 & + \\
Growth in $\mathrm{NaCl}$ & + \\
$3.0 \%$ & + \\
$6.5 \%$ & +
\end{tabular}

Growth at temperature

$15^{\circ} \mathrm{C}$

W

$20^{\circ} \mathrm{C}$

W

$25^{\circ} \mathrm{C}$

$+$

$30^{\circ} \mathrm{C}$

$+$

$35^{\circ} \mathrm{C}$

$+$

$40^{\circ} \mathrm{C}$

$+$

$45^{\circ} \mathrm{C}$

$+$

Fermentation of carbohydrate

Ribose

$+$

Galactose

$+$

D-glucose

$+$

D-fructose

$+$

D-manose

$+$

Maltose

$+$

Lactose

$+$

Melibiose

$+$

Sucrose

D-raffinose 
2 Gluconate

W

5-keto-gluconate

$+$ 


\section{Table 3 (on next page)}

Cultivable microbial population and $\mathrm{pH}$ values of alfalfa silage after 60 days of ensiling.

LAB, lactic acid bacteria; FM: fresh matter; S1: Sample1 (fresh); S2, Sample 2 (wilted in the field for 5 hours); CK, untreated control; CE, application of commercial cellulose; LF, application of L. fermentum 17SD-2; LF+CE: combination of L. fermentum 17SD-2 and commercial CE; SEM: Standard error of mean. ND, not detected; NA, Not applicable.

${ }^{1}$ WC, water content; A: Additives; WC $\times A$ : the interaction between water content and additives. 
1

\begin{tabular}{|c|c|c|c|c|}
\hline Items & $\begin{array}{c}\text { LAB } \log \text { CFU/g } \\
\text { FM }\end{array}$ & $\begin{array}{c}\text { Yeast } \log \text { CFU/g } \\
\text { FM }\end{array}$ & $\begin{array}{c}\text { Mold } \log \text { CFU/g } \\
\text { FM }\end{array}$ & pH value \\
\hline \multicolumn{5}{|c|}{ S1 group } \\
\hline CK & $6.9 \pm 0.019^{c}$ & $4.6 \pm 0.0071$ & ND & $6.8 \pm 0.038^{\mathrm{a}}$ \\
\hline CE & $7.3 \pm 0.019^{b}$ & ND & ND & $5 \pm 0.026^{\mathrm{d}}$ \\
\hline LF & $7.3 \pm 0.015^{b}$ & ND & ND & $5.4 \pm 0.041^{\mathrm{c}}$ \\
\hline $\mathrm{LF}+\mathrm{CE}$ & $7.4 \pm 0.019^{b}$ & ND & ND & $4.7 \pm 0.032^{\mathrm{e}}$ \\
\hline \multicolumn{5}{|c|}{ S2 group } \\
\hline CK & $6.8 \pm 0.024^{c}$ & $4.5 \pm 0.038$ & ND & $6.1 \pm 0.038^{b}$ \\
\hline $\mathrm{CE}$ & $7.4 \pm 0.074^{b}$ & ND & ND & $5.1 \pm 0.018^{\mathrm{d}}$ \\
\hline LF & $7.6 \pm 0.046^{\mathrm{a}}$ & ND & ND & $5.3 \pm 0.074^{c}$ \\
\hline $\mathrm{LF}+\mathrm{CE}$ & $7.4 \pm 0.014^{b}$ & ND & ND & $4.8 \pm 0.036^{\mathrm{e}}$ \\
\hline SEM & 0.049 & 0.019 & NA & 0.058 \\
\hline \multicolumn{5}{|c|}{ Main effects ${ }^{1}$} \\
\hline WC & 0.132 & 0.052 & NA & $<0.001$ \\
\hline A & $<0.001$ & $<0.001$ & NA & $<0.001$ \\
\hline $\mathrm{WC} \times \mathrm{A}$ & 0.003 & 0.019 & NA & $<0.001$ \\
\hline
\end{tabular}




\section{Table 4 (on next page)}

Fermentation characteristic and chemical composition in alfalfa silage.

LA, lactic acid; $A A$, acetic acid; LA/AA, the ratio of lactic acid and acetic acid; $B A$, butyric acid; $\mathrm{NH}_{3}-\mathrm{N}$, ammonia-N; DM, dry matter; $C P$, crude protein; NDF, neutral detergent fiber; ADF, acid detergent fiber; WSC, water soluble carbohydrates; S1: Sample1 (fresh); S2, Sample 2 (wilted in the field for 5 hours); CK, untreated control; CE, application of commercial cellulose; LF, application of L. fermentum 17SD-2; LF+CE: combination of $L$. fermentum 17SD-2 and commercial CE; SEM: Standard error of mean. ND, not detected; NA, Not applicable.

${ }^{1}$ WC, water content; A: Additives; WCXA: the interaction between water content and additives. 


\begin{tabular}{|c|c|c|c|c|c|c|c|c|c|c|}
\hline Items & LA & $\mathbf{A A}$ & LA/AA & BA & DM & $\mathbf{C P}$ & $\mathbf{N H}_{3}-\mathrm{N}$ & NDF & ADF & WSC \\
\hline \multicolumn{11}{|l|}{ S1 group } \\
\hline $\mathrm{CK}$ & $2.8 \pm 0.13^{\mathrm{d}}$ & $5.3 \pm 0.047^{\mathrm{a}}$ & $0.52 \pm 0.028^{\mathrm{d}}$ & $2.6 \pm 0.11^{\mathrm{a}}$ & $20 \pm 0.094^{\mathrm{e}}$ & $18 \pm 0.05^{\mathrm{f}}$ & $1.8 \pm 0.014^{\mathrm{a}}$ & $38 \pm 0.089^{\mathrm{a}}$ & $30 \pm 0.095^{\mathrm{a}}$ & $0.58 \pm 0.012^{\mathrm{e}}$ \\
\hline $\mathrm{CE}$ & $9.8 \pm 0.24^{a}$ & $5.3 \pm 0.057^{\mathrm{a}}$ & $1.8 \pm 0.026^{\mathrm{b}}$ & $1.2 \pm 0.011^{\mathrm{b}}$ & $20 \pm 0.078^{\mathrm{d}}$ & $21 \pm 0.15^{\mathrm{e}}$ & $0.95 \pm 0.026^{\mathrm{b}}$ & $32 \pm 0.023^{\mathrm{d}}$ & $25 \pm 0.035^{\mathrm{d}}$ & $0.64 \pm 0.0088^{\mathrm{d}}$ \\
\hline $\mathrm{LF}$ & $6.3 \pm 0.36^{\mathrm{b}}$ & $4.7 \pm 0.048^{b}$ & $1.3 \pm 0.065^{\mathrm{c}}$ & $0.84 \pm 0.06^{\mathrm{d}}$ & $21 \pm 0.084^{\mathrm{d}}$ & $21 \pm 0.066^{\mathrm{d}}$ & $0.88 \pm 0.018^{c}$ & $34 \pm 0.068^{b}$ & $27 \pm 0.071^{\mathrm{b}}$ & $0.52 \pm 0.015^{\mathrm{f}}$ \\
\hline $\mathrm{LF}+\mathrm{CE}$ & $11 \pm 0.31^{\mathrm{a}}$ & $4.2 \pm 0.039^{c}$ & $2.5 \pm 0.067^{\mathrm{a}}$ & $1 \pm 0.068^{c}$ & $23 \pm 0.27^{c}$ & $25 \pm 0.05^{\mathrm{a}}$ & $0.57 \pm 0.026^{\mathrm{de}}$ & $28 \pm 0.038^{\mathrm{g}}$ & $22 \pm 0.076^{\mathrm{f}}$ & $0.98 \pm 0.015^{\mathrm{b}}$ \\
\hline \multicolumn{11}{|l|}{ S2 group } \\
\hline CK & $1.8 \pm 0.2^{\mathrm{e}}$ & $2.9 \pm 0.023^{\mathrm{f}}$ & $0.62 \pm 0.074^{\mathrm{d}}$ & $0.57 \pm 0.018^{\mathrm{e}}$ & $27 \pm 0.14^{b}$ & $22 \pm 0.043^{c}$ & $0.53 \pm 0.012^{\mathrm{e}}$ & $33 \pm 0.084^{c}$ & $26 \pm 0.032^{\mathrm{c}}$ & $1.2 \pm 0.018^{\mathrm{a}}$ \\
\hline $\mathrm{CE}$ & $5.9 \pm 0.38^{b}$ & $3.6 \pm 0.031^{\mathrm{d}}$ & $1.6 \pm 0.099^{b}$ & $0.54 \pm 0.012^{\mathrm{e}}$ & $27 \pm 0.24^{\mathrm{b}}$ & $24 \pm 0.044^{b}$ & $0.59 \pm 0.019^{\mathrm{d}}$ & $29 \pm 0.19^{\mathrm{e}}$ & $23 \pm 0.09^{\mathrm{e}}$ & $1.2 \pm 0.015^{\mathrm{a}}$ \\
\hline LF & $4 \pm 0.2^{\mathrm{c}}$ & $3.2 \pm 0.058^{\mathrm{e}}$ & $1.2 \pm 0.074^{\mathrm{c}}$ & $0.58 \pm 0.028^{\mathrm{e}}$ & $27 \pm 0.34^{\mathrm{b}}$ & $22 \pm 0.077^{\mathrm{c}}$ & $0.47 \pm 0.0063^{\mathrm{f}}$ & $34 \pm 0.27^{\mathrm{bc}}$ & $26 \pm 0.26^{\mathrm{c}}$ & $0.79 \pm 0.0088^{c}$ \\
\hline $\mathrm{LF}+\mathrm{CE}$ & $6.7 \pm 0.21^{b}$ & $2.9 \pm 0.011^{\mathrm{f}}$ & $2.4 \pm 0.083^{\mathrm{a}}$ & $1 \pm 0.0028^{c}$ & $30 \pm 0.09^{\mathrm{a}}$ & $25 \pm 0.061^{\mathrm{a}}$ & $0.38 \pm 0.01^{\mathrm{g}}$ & $29 \pm 0.16^{f}$ & $23 \pm 0.055^{\mathrm{e}}$ & $1.2 \pm 0.0088^{\mathrm{a}}$ \\
\hline SEM & 0.38 & 0.06 & 0.097 & 0.073 & 0.27 & 0.11 & 0.025 & 0.2 & 0.16 & 0.018 \\
\hline \multicolumn{11}{|l|}{$\begin{array}{l}\text { Main } \\
\text { effects }^{1}\end{array}$} \\
\hline WC & $<0.001$ & $<0.001$ & 0.103 & $<0.001$ & $<0.001$ & $<0.001$ & $<0.001$ & $<0.001$ & $<0.001$ & $<0.001$ \\
\hline A & $<0.001$ & $<0.001$ & $<0.001$ & $<0.001$ & $<0.001$ & $<0.001$ & $<0.001$ & $<0.001$ & $<0.001$ & $<0.001$ \\
\hline $\mathrm{WC} \times \mathrm{A}$ & $<0.001$ & $<0.001$ & 0.193 & $<0.001$ & 0.002 & $<0.001$ & $<0.001$ & $<0.001$ & $<0.001$ & $<0.001$ \\
\hline
\end{tabular}




\section{Table 5 (on next page)}

Alpha diversity of bacterial community after 60 days of ensiling.

S1: Sample1 (fresh); S2, Sample 2 (wilted in the field for 5 hours); CK, untreated control; CE, application of commercial cellulose; LF, application of L. fermentum 17SD-2; LF+CE: combination of $L$. fermentum 17SD-2 and commercial CE; SEM: Standard error of mean. ND, not detected; NA, Not applicable.

${ }^{1}$ WC, water content; A: Additives; WCXA: the interaction between water content and additives. 


\begin{tabular}{ccccccc}
\hline Items & $\begin{array}{c}\text { Observed } \\
\text { species }\end{array}$ & Chao 1 & Shannon & Simpson & ACE & Coverage \\
\hline S1 group & & & & & & \\
CK & $85 \pm 5.6^{\mathrm{b}}$ & $110 \pm 20^{\mathrm{bc}}$ & $2.4 \pm 0.084^{\mathrm{a}}$ & $0.15 \pm 0.015^{\mathrm{ce}}$ & $140 \pm 34^{\mathrm{ab}}$ & 0.99 \\
CE & $57 \pm 3.5^{\mathrm{cd}}$ & $100 \pm 26^{\mathrm{bc}}$ & $2.1 \pm 0.014^{\mathrm{b}}$ & $0.17 \pm 0.0044^{\mathrm{cd}}$ & $120 \pm 6.7^{\mathrm{b}}$ & 0.99 \\
LF & $130 \pm 3.5^{\mathrm{a}}$ & $160 \pm 6.8^{\mathrm{a}}$ & $2.4 \pm 0.032^{\mathrm{a}}$ & $0.14 \pm 0.0064^{\mathrm{de}}$ & $180 \pm 9.7^{\mathrm{a}}$ & 0.99 \\
LF+CE & $85 \pm 1.2^{\mathrm{b}}$ & $150 \pm 25^{\mathrm{ab}}$ & $2 \pm 0.074^{\mathrm{b}}$ & $0.2 \pm 0.016^{\mathrm{c}}$ & $180 \pm 30^{\mathrm{a}}$ & 0.99 \\
S2 group & & & & & & \\
CK & $80 \pm 3.8^{\mathrm{b}}$ & $100 \pm 3.4^{\mathrm{bc}}$ & $2.5 \pm 0.084^{\mathrm{a}}$ & $0.12 \pm 0.01^{\mathrm{e}}$ & $140 \pm 7.4^{\mathrm{ab}}$ & 0.99 \\
CE & $55 \pm 3^{\mathrm{cd}}$ & $75 \pm 11^{\mathrm{c}}$ & $2 \pm 0.037^{\mathrm{b}}$ & $0.18 \pm 0.0063^{\mathrm{cd}}$ & $83 \pm 19^{\mathrm{b}}$ & 0.99 \\
LF & $66 \pm 3.5^{\mathrm{c}}$ & $100 \pm 6.5^{\mathrm{bc}}$ & $1.2 \pm 0.076^{\mathrm{c}}$ & $0.51 \pm 0.031^{\mathrm{b}}$ & $130 \pm 4.3^{\mathrm{ab}}$ & 0.99 \\
LF+CE & $53 \pm 3.8^{\mathrm{d}}$ & $70 \pm 10^{\mathrm{c}}$ & $1.1 \pm 0.036^{\mathrm{c}}$ & $0.58 \pm 0.015^{\mathrm{a}}$ & $85 \pm 2.5^{\mathrm{b}}$ & 0.99 \\
SEM & 5.2 & 22 & 0.085 & 0.021 & 26 & NA \\
Main & & & & & & \\
effects ${ }^{\mathrm{b}}$ & & & & & & \\
WC & $<0.001$ & 0.001 & $<0.001$ & $<0.001$ & 0.003 & NA \\
A & $<0.001$ & 0.077 & $<0.001$ & $<0.001$ & 0.054 & NA \\
WC $\times A$ & $<0.001$ & 0.237 & $<0.001$ & $<0.001$ & 0.093 & NA \\
\hline
\end{tabular}

